\title{
Design and Build Chatroom Application as Student Consultation Media Based on Android
}

\author{
Alvian Bastian 1,a, Muhammad Affiq Solihin ${ }^{2, b}$, Anggi Amelia Irdan ${ }^{3, c}$, and Novita Maulidya Jalal ${ }^{4, d}$ \\ 1,2,3 Electrical Engineering Department, Politeknik Negeri Ujung Pandang, Jl. Perintis Kemerdekaan KM. 10, Makassar, \\ 90245, Indonesia \\ ${ }^{4}$ Fakultas Psikologi, Universitas Negeri Makassar, Jl. AP. Pettarani, Makassar, 90222, Indonesia \\ a alvianbastian@poliupg.ac.id, ${ }^{\mathrm{b}}$ muhammadaffiqsolihin9701@gmail.com, ${ }^{\mathrm{c}}$ anggiameliairdan51@gmail.com, ${ }^{\mathrm{d}}$
}

\begin{abstract}
To support the government's program in preventing the spread of COVID-19 virus, it is expected to reduce direct communication between fellow students and lecturers. The purpose of this research to create interactive media that can provide consulting service for students with academic advisor (PA) without direct contact. It is expected for this research, students can be more proactive in interacting with their academic advisor in discussing academic and non-academic problems. The method used in this research is using Android Studio and Visual Studio Code as an Integrated Development Environment (IDE) and using a no-relational (NoSQL) realtime database on firebase. The advantage of this research is that the system to be developed does not use physical servers anymore but all databases are stored in the cloud system. The result of this research is chatroom application consisting of 7 modules namely application login with username and password, searching user, chatting user, list consultation, student input consultation, edit data consultation, and account setting.
\end{abstract}

Keywords-covid-19 prevention; chatroom; application; lecturer; student; consultation; android

\section{Introduction}

College as an educational unit providing higher education has a strategic role in educating the nation's life and advancing science and technology with the application of humanities values as well as sustainable culture and empowerment of the Indonesian nation. The strategic role makes higher education institutions a place of learning for students and the community as well as an educational forum for future leaders of the nation. This is in line with the mission of the Ujung Pandang State Polytechnic (PNUP) to be able to empower human resources on a going basis and to create noble academic community.

In order to educate the nation's life, each university is expected to lead its students to achieve academic success, career planning, and social life so that the assistance and role of Academic Advisor Lecturer (PA) is needed. Academic advisor can affect the academic success of students and is the key to the progress of student development. PA becomes a liason between students and universities where the success of a university is based on the success of its graduates.

Research in [1] suggests that the role of PA lecturer is more for guidance in the academic field and not yet on non-academic guidance. The majority of students think that PA lecturer function to consult about academic problems so that only few consults with PA lecturer with they encounter problems, especially about non-academic problems. This condition is due to the lack of proactiveness of students and lecturers in communicating, especially during the current pandemic, as well as students' doubts about the confidentially of the problems they share, so they feel ashamed to express them directly. Seeing the conditions, technology-based alternatives solutions are needed to provide consulting services to students.

To overcome the problems mentioned above, several studies have been carried out previously. Ref [2] created a decision system to facilitate student consultation with academic advisor in terms of choosing courses. The research is based on Android operating system and the method used is NodeJS and DBMS MySQL. Research in [3] discussed about online counseling websites for students in SMAN 1 Gresik. The method used is by using online counseling website, making it easier for BK teachers and students to conduct counseling outside of school hours. Research [4] which made an identification system and increased mental health resilience for 
students. The method used is a JSP-based web application and servlets as well as a MySQL database.

Research in [5] aims to create a web application for the relationship and interaction between students and their teachers using the real-time peer-to-peer communication (WebRTC) method. Ref [6] aims to create chat application for smartphone without force close but has not been able to make voice and video calls and cannot sends documents. Chat application between user to communicate with each other using text media are introduced [7]. The result of this study indicates that this application can be used to chat and send pictures but cannot be used for voice calls and video calls. Research that conducted in [8] aims to create a chat application so that users can receive and send information in form of text. This research uses a method based on the XMPP and Openfire protocols as a platform and uses the Kotlin programming language as the backend and MySQL as the local database server.

Different with the previous studies, this research allows students and lectures to conduct consultations through chatroom application in academic and nonacademic fields for benefit of students' selfdevelopment. To make it easier to use, this research is carried out based on Android. This research employs Android Studio and Visual Studio Code as an Integrated Development Environment (IDE) and using a norelational (NoSQL) real-time database on firebase. Android Studio provide tools for testing, app development phases and unified development publications to build apps on all Android devices [9].

Some research using Android Studio has been done before. For example, research in [10] make goods promotion applications, sports platform applications [11], experimental teaching system design [12], and interactive Android-based mobile applications that provide information and maps [13]. Ref [14] used Visual Studio Code for the creation of Android-based applications for vehicle owners. Research in [15] used
Visual Studio Code for Android and Web applications on a Car Rental Information System.

This student consulting application also uses a realtime database on firebase where its database is norelational (NoSQL) so that data changes can be done automatically. Another advantage on this research is that all databases are stored in the cloud so that it can be accessed anywhere and do not require a physical server anymore. Student can access this application through username and password. Users can access this application through the username and password previously provided.

\section{Research Methodology}

\section{A. Data Collection Technique}

Data collection is conducted through two methods:

1. Direct Observation by looking at the consultation activities carried out by Academic Advisor (PA).

2. Literature Study by reading references from previous research.

\section{B. System Planning}

The design of system uses the concept of Object Oriented Design (ODD) with UML. Login system for this application is by using email authentication system on firebase and the sign-in method using google email. Admin can set login authentication on firebase. In general, method for authentication login via email and password as follows:

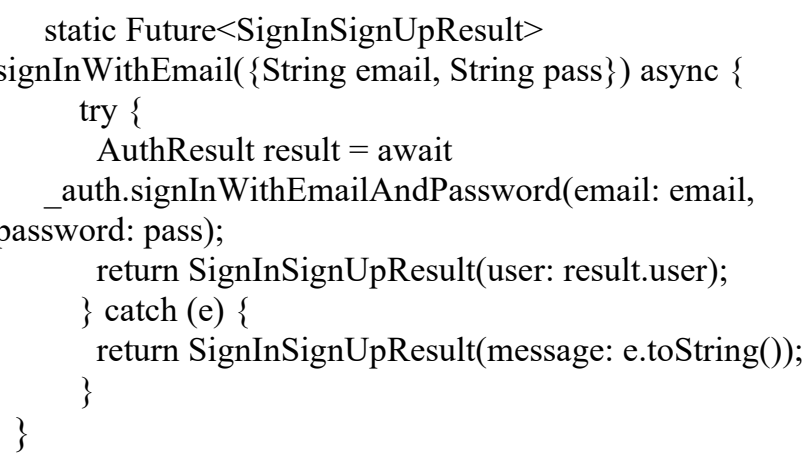


Apart from being a chat communication medium between academic advisor and students, a Chatroom application can also be used as a data storage media for student consultations. In general, the methods used for storing student consultation data are as follows:

CollectionReference reference $=$

Firestore.instance.collection('task'); await reference.add $(\{$

"email": firebaseUser.email,

"title": newTask,

"duedate": _dueDate,

"note": note,

\}$)$;

An overview of the application design as follows:

\section{Use Case Diagram}

Use Case Diagram in the design of application is depicted in the following figure:

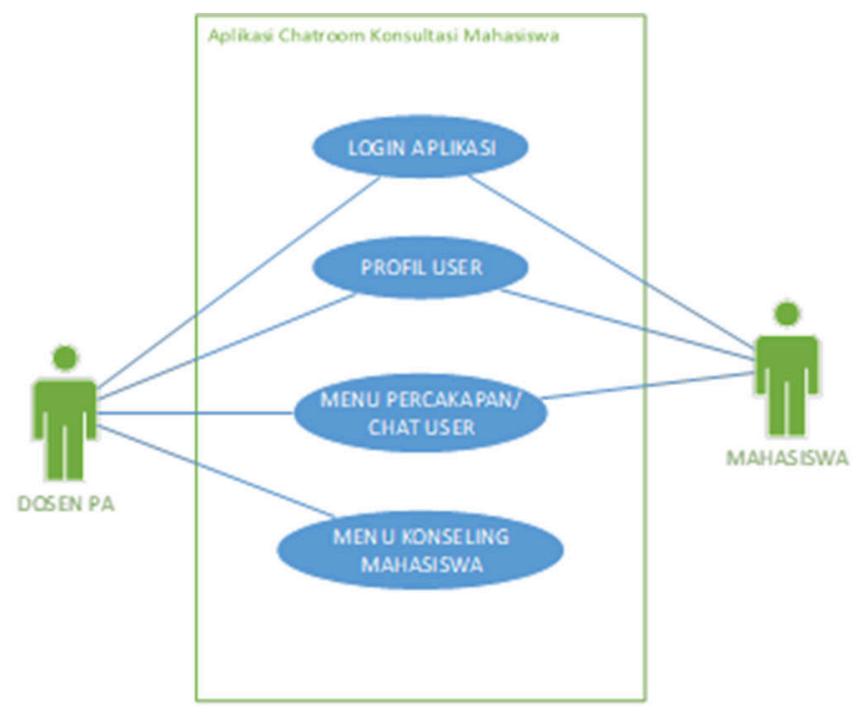

Figure 1. Use Case Diagram

2. Activity Diagram

Use Case Diagram in the design of application is depicted in the following figure:

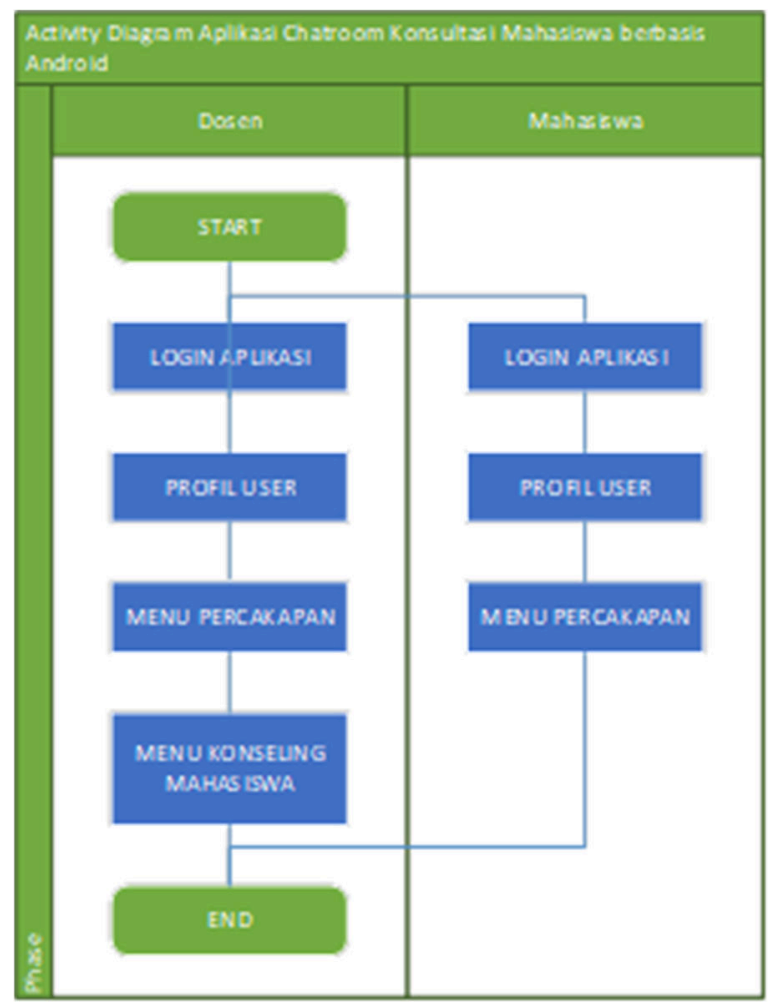

Figure 2. Activity Diagram

3. Database Design

For data storage using Firebase Realtime Database. Firebase uses JSON tree, database design in the design of application is depicted in the following figure:

\section{Chatroom Akademik}

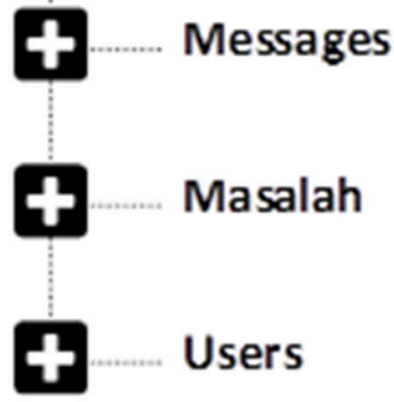

Figure 3. Database Design 


\section{User Interface}

User Interface is an application display that be created where users can run application and store data. User Interface in the design application is depicted in the following figure:
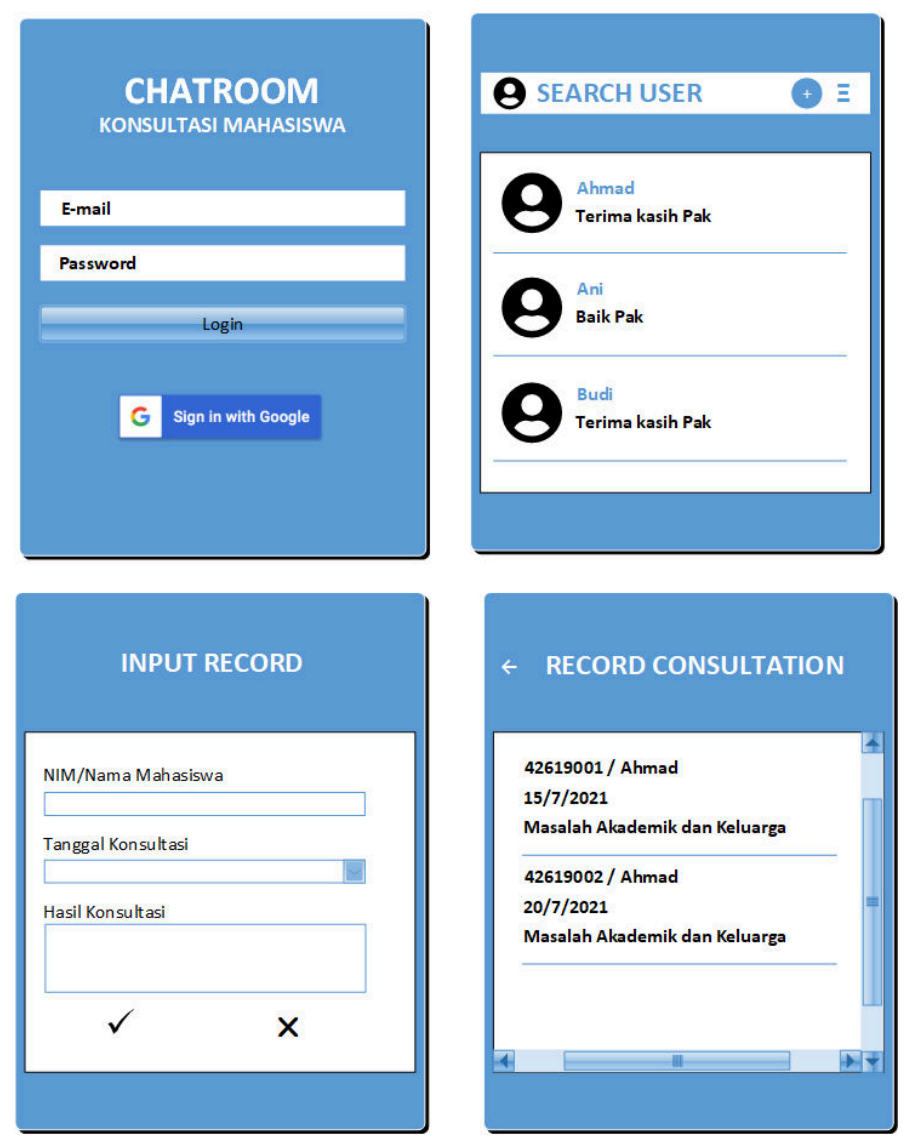

Figure 4. User Interface

\section{Testing}

Testing to ensure the system free from errors. This research using a black box for testing. The test results are caried out with adjust the program design output and expected results.

\section{Results and Discussion}

The result of this research is a chatroom application that can be used to communicate between academic advisor (PA) and students which consists of the following modules:

\section{Application Login}

Module for login into application by using username and password.

\section{Searching User}

Module for searching user when starting chat.

3. User chatroom

Module for starting chat between academic advisor and students.

4. List Consultation

Module for saving list of student consultation, student problem data, and date of consultation.

5. Input Data Student Consultation

Module for inputing student problem data after consultation with academic advisor.

\section{Edit Data Consultation}

Module for edit student problem data in application.

\section{Account Settings}

Module for show profile user, update profile, and logout from application.

View of chatroom application is depicted in the figure 5. The tests carried out show the suitability between the program design and the appearance of the application program. Testing is done by looking at the success of the functionality of the login page, search page, conversation page, consulting data input page, consulting data testing, and account settings page. 

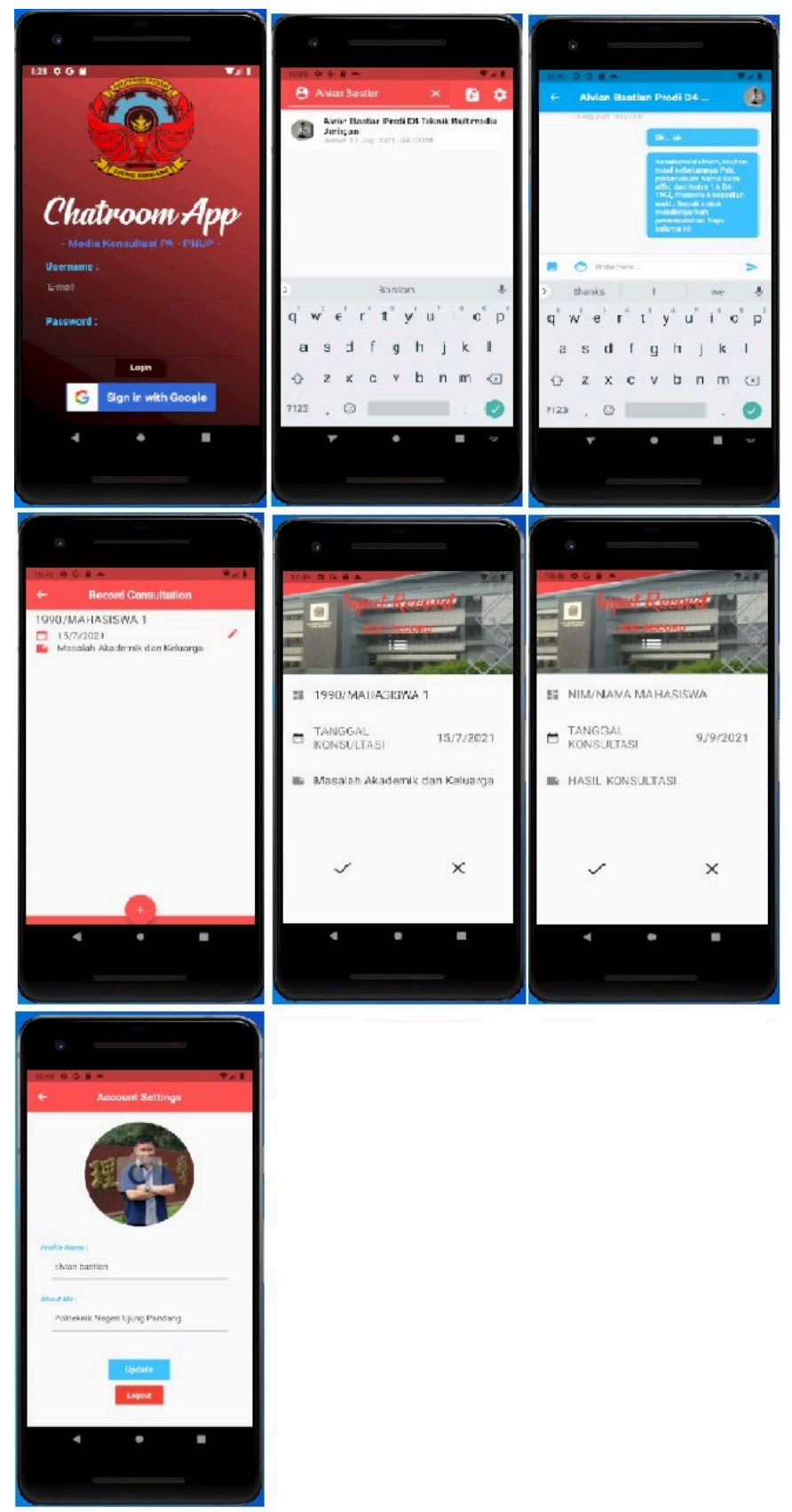

Figure 5. View of Chatroom Application

\section{Conclusion}

Based on the design and implementation of the chatroom application as well as inputting student consultation data based on Android, it can be concluded that through the chatroom application, academic advisor can reduce physical contact with students because they can communicate online via mobile application. Modules created in the chatroom application can run well so that it can be used to communicate between academic advisor and students. Confidentiality of student problems is guaranteed because data consultation can only be seen by academic advisor. Through the student consultation data input module, it is easier for academic advisor to manage their students' problems.

\section{Acknowledgement}

Acknowledgments are given to all those who have assisted in the completion of this research, especially to the Research Unit and Community Service at the State Polytechnic of Ujung Pandang and the Department of Electrical Engineering in terms of application testing.

\section{References}

[1] N. M. Jalal, E. Abdullah, and L. Nadjamuddin, "Persepsi Mahasiswa Tentang Efektivitas Pembimbingan Akademik", (Student Perceptions about the Effectiveness of Academic Guidance), J. IKRA-ITH Hum., Vol. 4, No. 3, pp. 179-186, 2020.

[2] A. S. H. Ilyas, "Pengembangan Sistem Pendukung Keputusan Pemrograman Mata Kuliah dengan Penasehat Akademik Virtual berbasis Android," (Development of a Course Programming Decision Support System with an Android-based Virtual Academic Advisor), Universitas Islam Negeri (UIN) Alauddin Makassar, 2016.

[3] Y. Prahesti, "Pengembangan Website Konseling Online Untuk Siswa di SMAN 1 Gresik", (Development of Online Counseling Website for Students in SMAN 1 Gresik), J. BK UNESA, Vol. 7, No. 3, pp. 144-154, 2017.

[4] R. Roy, R. Guha, S. Das Bhattacharya, and J. Mukhopadhyay, "Building a web based cognitive restructuring program for promoting resilience in a college campus," in 2017 9th International Conference on Communication Systems and Networks, COMSNETS 2017, 2017, pp. 520-524, doi: 10.1109/COMSNETS.2017.7945446.

[5] N. Pandey and D. Bein, "Web application for social networking using RTC," 2018, doi: 10.1109/CCWC.2018.8301692.

[6] M. Agung, Roslina, and R. E. Sari, "Implementasi aplikasi pembuatan chat," (Implementation of The Chat Creation Application), J. FTIK, Vol. 1, No. 1, pp. 293-306, 2019. 
[7] R. S. B. Daniarsyah, "Aplikasi dan Server Chat Online Berbasis Android", (Android Based Online Chat Applications and Servers), in e-Proceeding of Applied Science, 2020, pp. 1924-1938.

[8] M. D. Agustyani, "Aplikasi Chatting Menggunakan Kotlin di Android Berbasis Protokol XMPP", (Chat Application Using Kotlin on Android Based on XMPP Protocol), Sekolah Tinggi Manajemen Informatika dan Komputer Akakom Yogyakarta, 2020.

[9] Google Developer Training Team, Android Developer Fundamental Course: Learn to Develop Android Applications. Google Developer Training Team, 2017.

[10] N. H. Alosaimi, N. M. Elzein, and A. M. Tukka, "Mobile Application for Productive Families Business," 2020, doi: 10.1109/ICCAIS48893.2020.9096736.

[11] G. Li and X. Huang, "Research and Technology Development of University Campus Sports Data Platform,"
2020, doi: 10.1109/ICAICA50127.2020.9182488.

[12] J. Li, Y. Feng, and L. Jing, "Design and application of civil engineering experimental teaching management platform in mobile environment," 2020, doi: 10.1109/ICITBS49701.2020.00106.

[13] E. Wijayanto and Suyoto, "Development of smart workshop mobile application as information," 2020, doi: 10.1109/WorldS450073.2020.9210307.

[14] D. K. Szulim, "Mobile application supporting vehicle owners "CarCare," Warsaw University of Technology, 2021.

[15] M. H. Romadhon, "Sistem Informasi Rental Mobil Berbasis Android dan Website Menggunakan Framework Codeigniter 3", (Android-Based Car Rental Information System and Website Using the Codeigniter 3 Framework), Studi Kasus : CV Kopja Mandiri,” J. Sist. Inf. dan Teknol. Perad., Vol. 2, No. 1,2021 . 